$\mathrm{K}$

\title{
WOLNOŚĆ RELIGIJNA JAKO INSTRUMENT OCHRONY PRAWNEJ PRZECIWNIKÓW MAŁŻEŃSTW JEDNOPŁCIOWYCH. ZMIANY W PRAWIE STANU MISSISIPI PO WYDANIU ORZECZENIA W SPRAWIE OBERGEFELL $V$. HODGES
}

\author{
Streszczenie
}

Przedmiotem rozważań zawartych w niniejszym artykule są dokonywane ostatnio w Missisipi zmiany legislacyjne, będące reakcją zwolenników tradycyjnej koncepcji małżeństwa na legalizację małżeństw pomiędzy osobami tej samej płci. Szczególna uwaga zwrócona jest na Mississippi Religious Freedom Restoration Act i Protecting Freedom of Conscience from Government Discrimination Act. $\mathrm{Na}$ ich kanwie przedstawiono reakcję konserwatywnych środowisk stanu Missisipi na orzeczenie Obergefell v. Hodges, jak również kontrreakcję ruchu LGBT. Przeprowadzone analizy uwidaczniają napięcie, jakie istnieje pomiędzy zasadami równości i wolności religijnej, interpretowanymi w myśl założeń przyjmowanych przez przeciwne strony sporu. Prowadzi to do konkluzji, że nie istnieją prawne możliwości rozwiązania tego konfliktu na drodze kompromisu. Zgodnie z tezą artykułu, gwarancje wolności religijnej mogą natomiast stać się instrumentem ochrony prawnej oponentów małżeństw homoseksualnych przed zarzutami o dyskryminację w sytuacjach, gdy wyznawana przez nich religia nie pozwala im na uznanie za małżeństwo związku osób tej samej płci.

Słowa kluczowe: wolność religijna; równość wobec prawa; małżeństwa osób tej samej płci; Missisipi HB 1523

$* * * * *$

* Dr hab., prof. KUL, Katedra Historii Ustroju i Prawa, Wydział Prawa, Prawa Kanonicznego i Administracji, Katolicki Uniwersytet Lubelski Jana Pawła II, Al. Racławickie 14, 20-950 Lublin; Fulbright Scholar-in-Residence w Delta State University, Cleveland, Missisipi; e-mail: kzasepa@kul.pl. ORCID 0000-0002-1744-931X. 


\section{WPROWADZENIE}

Unormowanie prawne tzw. związków partnerskich w USA w relatywnie krótkim czasie doprowadziło do zmiany tradycyjnej definicji małżeństwa. Początkowo związki partnerskie miały stanowić swego rodzaju kompromis między oczekiwaniami ruchu LGBT ${ }^{1}$, który postulował umożliwienie parom homoseksualnym zawarcie małżeństwa, oraz poglądami tej części społeczeństwa, dla której małżeństwo może zostać zawarte wyłącznie przez mężczyznę i kobietę. Ostatecznie w prawie amerykańskim usankcjonowano małżeństwa osób tej samej płci. Nastąpiło to na kanwie orzeczenia federalnego Sądu Najwyższego z 2015 r. w sprawie Obergefell v. Hodges ${ }^{2}$, w którym za niekonstytucyjne uznano regulacje prawne odmawiające parom homoseksualnym prawa do zawarcia związku małżeńskiego. Z uwagi na brak akceptacji dla skutków tego orzeczenia wśród zwolenników małżeństwa jako związku między osobami odmiennej płci, w wielu stanach zainicjowano działania legislacyjne, które - w skrócie rzecz ujmując - miały chronić tę grupę przed zarzutem dyskryminacji w sytuacjach, w których ich działania mogły być postrzegane jako uprzywilejowanie małżeństw zawieranych między mężczyzną a kobietą.

Zasygnalizować należy, że niniejszy artykuł nie podejmuje zagadnienia, czy w świetle orzeczenia w sprawie Obergefell v. Hodges i ze względu na system prawa precedensowego obowiązujący w USA, tego rodzaju działania legislacyjne ze swej istoty mogą zostać uznane za dyskryminacyjne. Cel artykułu stanowi bowiem próba obiektywnego i niewartościującego przedstawienia zmian w prawie zachodzących wskutek legalizacji małżeństw homoseksualnych, w których - dążąc do ochrony tradycyjnego

1 Lesbians, Gays, Bisexuals, Transgenders (lesbijki, geje, biseksualiści, osoby transpłciowe).

2 Obergefell v. Hodges, 576 U.S. (2015), https://www.supremecourt.gov/opinions/14pdf/14-556_3204.pdf [dostęp: 30.07.2020]. Samo orzeczenie, ze względu na to, że stanowiło już przedmiot licznych analiz w polskiej literaturze przedmiotu, nie będzie szerzej omawiane w niniejszym artykule. Zob. Longchamps de Bérier 2016, 3-15; Wróbel 2016, 125-141; Łącki 2016, 169-183; Machaj 2019, 377-396. Problematykę małżeństw jednopłciowych w orzecznictwie sądów USA przed 2015 r. szeroko omówił Prostak 2014, 89-106. 
postrzegania małżeństwa - odwoływano się do wolności religijnej i wolności sumienia.

W ostatnich latach sądy amerykańskie mierzyły się nie tylko z problemem klauzuli sumienia w środowisku medycznym, ale także z odmowami wykonania obowiązku służbowego przez urzędników, przed którymi małżeństwo zawierały osoby tej samej płci³. Równolegle kontrowersje zaczęły budzić sytuacje, w których przedsiębiorcy odmawiali sprzedaży towarów i usług osobom homoseksualnym w związku z zawieranym przez nie małżeństwem, uzasadniając taką odmowę przekonaniami religijnymi lub moralnymi.

Działania legislacyjne będące reakcją na legalizację małżeństw osób tej samej płci podejmowano w wielu stanach. Warto jednak skoncentrować uwagę na przykładzie Missisipi, które zgodnie z prowadzonymi badaniami socjologicznymi uważane jest za najbardziej religijny (ok. 60\% ankietowanych deklaruje się tam jako osoby „bardzo religijne”4) oraz „,najbardziej konserwatywny" stan USA. Wyjaśnienia przy tym wymaga, że dla pewnego uproszczenia, w niniejszym artykule używa się niekiedy terminów „konserwatywny” i ,liberalny” w ich szerokim, publicystycznym znaczeniu. Pierwszy z nich jest wykorzystywany na określenie stanów czy grup społecznych będących zwolennikami tradycyjnego rozumienia małżeństwa, natomiast drugi jest odnoszony do adherentów koncepcji prawnego usankcjonowania małżeństw zawieranych między osobami tej samej płci.

Bazując na metodzie dogmatyczno-prawnej, w tym przede wszystkim analizie źródeł prawa, sformułowana została teza badawcza, iż gwarancje wolności religijnej mogą stać się instrumentem ochrony prawnej oponentów małżeństw homoseksualnych przed zarzutami o dyskryminację, w sytuacjach gdy wyznawana przez nich religia nie pozwala im na uznanie za małżeństwo związku osób tej samej płci. Członkowie tej grupy domagają się bowiem nie tylko możliwości otwartego głoszenia swoich poglądów w kwestii definiowania małżeństwa, ale i wolności w zakresie podejmowanych zachowań związanych z wykonywaną przez nich pracą, jeśli miałyby

\footnotetext{
$2018,3$.

O niektórych tego rodzaju postępowaniach wzmiankują Kazyak, Burke, Stange

$4 \mathrm{https}: / /$ news.gallup.com/poll/203747/mississippi-retains-standing-religious-state. aspx [dostęp: 10.11.2020].
} 
one skutkować działaniem na rzecz małżeństw homoseksualnych. Należy zwrócić szczególną uwagę na to, iż z racji na potencjalny zakres zarzutów o dyskryminację, problematyka powyższa dotyczy nie tylko osób zatrudnionych w sektorze publicznym, ale również prywatnym. W toczącej się na ten temat dyskusji punktem odniesienia stało się orzeczenie federalnego Sądu Najwyższego w sprawie Masterpiece Cakeshop, LTD. v. Colorado Civil Rights Commission z 2018 r. Dotyczyło ono właściciela ciastkarni w Kolorado, który w 2012 r. odmówił wykonania tortu weselnego dla pary homoseksualnej, argumentując to swoimi przekonaniami religijnymi. Zaistniały spór został przedstawiony stanowej Komisji Praw Obywatelskich, która orzekła, iż taka odmowa stanowi akt dyskryminacji, mimo że w 2012 r. stan Kolorado nie uznawał jeszcze związków małżeńskich między osobami tej samej płci. Sąd Najwyższy orzekł, że tego rodzaju konflikty będą rozstrzygane na drodze precedensów zgodnie z zasadą tolerancji, a zatem z zachowaniem szacunku do poglądów religijnych i bez narażania osób homoseksualnych na poniżenie, gdy nabywają one towary lub zamawiają usługi na otwartym rynku. Sąd dostrzegł jednak, że działania Komisji nie były neutralne, lecz wrogie w stosunku do religii wyznawanej przez właściciela ciastkarni, a przez to niezgodne z obowiązującym prawem $^{5}$. Warto dodać, że do tego orzeczenia nawiązał w ostatnim czasie sędzia Samuel Alito w swoim przemówieniu z dnia 12 listopada 2020 r. wygłoszonym przed Federalist Society, które odbiło się niezwykle szerokim echem w dyskusji publicznej. Sędzia Alito stwierdził bowiem, że wolność religijna jest zagrożona i może stać się prawem drugiej kategorii. Podniósł on między innymi, iż obecnie za niedopuszczalną zaczyna być uważana opinia, którą do niedawna głosiła większość Amerykanów, a która dziś uznawana jest za bigoterię - że małżeństwo jest związkiem między mężczyzną a kobietą.

Nie ulega wątpliwości, że przy dynamicznie zmieniającym się układzie sił uczestniczących w sporze na temat definicji małżeństwa, odnoszące się do tego normy prawne (a także formułowane postulaty zmian) będą nadal stanowić przedmiot ożywionej debaty. Warto więc odwołać się

5 Masterpiece Cakeshop, LTD., et. al., Petitioners v. Colorado Civil Rights Commission, et. al., 584 U.S. (2018), https://www.supremecourt.gov/opinions/17pdf/16-111_j4el. pdf [dostęp: 10.11.2020]. 
do doświadczeń legislacyjnych jednego z bardziej konserwatywnych stanów USA.

\section{LEGALIZACJA MAŁŻEŃSTW MIĘDZY OSOBAMI TEJ SAMEJ PŁCI W MISSISIPI}

W pierwszej kolejności zaznaczyć trzeba, że w 1997 r. legislatura Missisipi uchwaliła przepisy (§ 93-1-1(2) Kodeksu Missisipi), na mocy których małżeństwa między osobami tej samej płci uznano za zabronione. Jednocześnie przyjęto, że małżeństwa homoseksualne zawarte w innych stanach nie będę uznane w prawie Missisipi ${ }^{6}$. W 2004 r. zmieniono nawet Konstytucję Missisipi, wprowadzając do niej § 263A. Przepisowi temu nadano następujące brzmienie: „Małżeństwo może zostać zawarte zgodnie z prawem tego Stanu tylko między mężczyzną a kobietą. Małżeństwa między osobami tej samej płci zawarte w innym Stanie lub w innym państwie, niezależnie od tego, gdzie zostały zawarte, nie będą uznawane przez ten Stan oraz są nieważne i niewykonalne według prawa tego Stanu"’.

Ową zmianę ustrojodawczą poprzedziło referendum, w którym poparło ją $86 \%$ głosujących przy frekwencji wynoszącej $54 \%{ }^{8}$. W tej sytuacji pierwsze próby legalizacji małżeństw osób homoseksualnych podjęła władza sądownicza. Najbardziej doniosłe znaczenie w tej materii miały orzeczenia wydane przez sędziego federalnego, Carltona W. Reevesa. W dniu 25 listopada 2014 r. w sprawie Campaign for Southern Equality

6 Kodeks Missisipi (Mississippi Code), https://advance.lexis.com oraz www.sos. ms.gov. [dostęp: 30.07.2020], § 93-1-1(2).

7 Konstytucja Missisipi z dnia 1 listopada 1890 r. (Constitution of Mississippi), www. sos.ms.gov. [dostęp: 30.07 .2020 ], $§ 263$ A: Marriage may take place and may be valid under the laws of this State only between a man and a woman. A marriage in another State or foreign jurisdiction between persons of the same gender, regardless of when the marriage took place, may not be recognized in this State and is void and unenforceable under the laws of this State. Warto dodać, że przepisy owe do dnia dzisiejszego nie zostały ani zmienione, ani usunięte - mimo wydania przez Sąd Najwyższy USA orzeczenia w sprawie Obergefell v. Hodges.

8 Za: https://uselectionatlas.org/RESULTS/state.php?fips=28\&year=2004\&f=0\&off $=50 \&$ elect $=0$ [dostęp: 30.07.2020]. 
v. Bryant (I) wydał on zakaz sądowy w trybie badania zgodności ustaw z Konstytucją USA (judicial review), orzekając tym samym o niezgodności wyżej wskazanych przepisów, tj. § 263A Konstytucji Missisipi oraz § 93-1-1(2) Kodeksu Missisipi z Poprawką XIV do Konstytucji USA. W uzasadnieniu postanowienia sędzia Reeves argumentował, że nawet jeśli większość mieszkańców Missisipi sprzeciwia się małżeństwom osób tej samej płci nie ze względu na uprzedzenia, lecz domagając się poszanowania dla wizji małżeństwa zgodnej z tradycją lub wyznawaną religią, to zakaz zawierania małżeństw przez osoby tej samej płci narusza zasadę równości wobec prawa, a z osób homoseksualnych czyni obywateli drugiej kategorii. Ponadto konkludował, że Missisipi zmienia się w sposób, którego nikt nie przewidywał 10 lat wcześniej i że zalegalizowanie małżeństw osób homoseksualnych nikogo nie krzywdzi. Wręcz przeciwnie $-\mathrm{w}$ jego ocenie - jest to mechanizm wspierający rodziny oraz dający stabilizację dzieciom wychowywanym w takich małżeństwach.

Co istotne, pół roku po wydaniu postanowienia przez sędziego Reevesa, to właśnie Sąd Najwyższy USA ostatecznie rozstrzygnął o obowiązku legalizacji małżeństw homoseksualnych, wydając orzeczenie w sprawie Obergefell v. Hodges, które wiąże wszystkie stany i - tym samym - ujednolica w skali całego federalnego systemu USA rozwiązania prawne w tej materii.

\section{WOLNOŚĆ RELIGIJNA JAKO PODSTAWA ODMOWY UZNANIA MAŁŻEŃSTWA MIĘDZY OSOBAMI TEJ SAMEJ PŁCI}

Wskutek legalizacji małżeństw jednopłciowych w orzecznictwie stanowym i federalnym, w Missisipi zainicjowano etap działań legislacyjnych zakotwiczonych w swobodzie praktyk religijnych i klauzuli sumienia jako podstaw do odmowy uznania małżeństw homoseksualnych. Wyjaśnienia w tym miejscu wymaga, że zgodnie z Konstytucją Missisipi „,...] wolność cieszenia się religijnymi zapatrywaniami oraz poszanowanie różnych sposobów oddawania czci są uznane za święte. Prawa te jednak nie mogą być wykorzystane do usprawiedliwienia aktów rozpusty szkodliwych dla moralności lub groźnych dla pokoju i bezpieczeństwa Stanu lub do uniemożliwienia korzystania z Pisma Świętego w szkołach publicznych w tym 
Stanie". Natomiast w orzeczeniu Mabus v. St. James Episcopal Church z 2004 r. ${ }^{10}$ stanowy Sąd Najwyższy zaakcentował, że tak zakreślone granice wolności religijnej pozostają spójne z Poprawką I do Konstytucji federalnej ${ }^{11}$.

Zasadnicze znaczenie w działaniach podjętych przez legislaturę Missisipi i mających na celu ochronę osób, których wierzenia religijne lub przekonania moralne nie pozwalają na uznanie związków małżeńskich zawieranych przez osoby tej samej płci posiadało uchwalenie dwóch aktów normatywnych. Pierwszym z nich była - wzorowana na federalnej poprzedniczce z 1993 r. - ustawa o przywróceniu wolności religijnej (Mississippi Religious Freedom Restoration Act, § 11-61-1 Kodeksu Missisipi $^{12}$ ), która weszła w życie 1 lipca 2014 r. W drugiej kolejności została uchwalona ustawa o ochronie wolności sumienia przed dyskryminacją ze strony władzy (Protecting Freedom of Conscience from Government Discrimination Act, §§ 11-62-2 do 11-62-19 Kodeksu Missisipi $\left.{ }^{13}\right)$, która weszła w życie 10 października $2017 \mathrm{r}$.

Przystępując do analizy obu ustaw należy najpierw odwołać się do ich zakresu podmiotowego. O ile bowiem konstytucyjne gwarancje wolności religijnej - co do zasady - bezpośrednio chronią dobro osób fizycznych i dopiero pośrednio mogą oddziaływać na osoby prawne, to w orzecznictwie amerykańskim ostatnich lat (czego wyrazem jest zwłaszcza wyrok federalnego Sądu Najwyższego z 2014 r. w sprawie Burwell v. Hobby Lobby Stores, Inc. ${ }^{14}$ ) rozszerzono krąg podmiotów mających bezpośrednie roszczenia na gruncie MRFRA ${ }^{15}$. Natomiast $\mathrm{w}$ drugiej $\mathrm{z}$ omawianych tu ustaw (HB 1523), definiując „osobę” stanowi się, że może to być osoba fi-

9 Konstytucja Missisipi, $\S 18$ : The free enjoyment of all religious sentiments and the different modes of worship shall be held sacred. The rights hereby secured shall not be construed to justify acts of licentiousness injurious to morals or dangerous to the peace and safety of the state, or to exclude the Holy Bible from use in any public school of this state.

10884 So. 2 d 747 (2004).

11 Zob. Linton 2013, 154.

12 Dalej także jako MRFRA.

13 Dalej także jako HB 1523 (ten powszechnie używany skrót pochodzi od nazwy projektu ustawodawczego).

14573 U.S. 682 (2014).

15 Zob. też Hodge, Jr. 2015, 547. 
zyczna, organizacja religijna, jednoosobowa działalność gospodarcza bądź inna osoba prawna. Wszystkie te podmioty - jeśli szukają ochrony wynikającej z tej ustawy - muszą odwoływać się do określonych przekonań religijnych lub moralnych ${ }^{16}$.

Przedstawiając rozwiązania zawarte w obowiązującej w Missisipi ustawie o przywróceniu wolności religijnej wskazać trzeba, że w preambule odwołano się do myśli Ojców-Założycieli Stanów Zjednoczonych i znaczenia wolności religijnej. Zaakcentowano mianowicie, że swobodne wykonywanie praktyk religijnych jest z założenia prawem niezbywalnym (unalienable right) i jako takie podlega ochronie Pierwszej Poprawki do Konstytucji USA. Podkreślono, że wymóg „,neutralności” może stanowić przeszkodę w swobodnym wykonywaniu praktyk religijnych. Zwrócono też uwagę, że władza nie może ograniczać tej wolności religijnej, chyba że istnieją ku temu ważne powody, które trzeba wyraźnie wskazać w uzasadnieniu ograniczenia ${ }^{17}$.

Warto dodać, że omawiana ustawa stanowiła odroczoną w czasie odpowiedź na orzeczenie federalnego Sądu Najwyższego w sprawie Employment Division v. Smith z 1990 r. Orzeczenie to bowiem istotnie zawęziło granice swobody praktyk religijnych poprzez uznanie, że władze nie muszą wskazywać tzw. „przemożnego interesu” (compelling interest), jeśli ograniczenia dotyczą wszystkich obywateli. W praktyce stosowania prawa zwolniło to sądy z dopełniania rygorów ścisłej kontroli (strict scrutiny), która w systemie amerykańskim jest konstytutywnym elementem zasady judicial review. Paradoksalnie, to sędzia Antonin Scalia był autorem uzasadnienia tego orzeczenia, które z czasem przyczyniło się do wykładania zasady religijnej neutralności państwa na niekorzyść środowisk konserwatywnych. W uzasadnieniu orzeczenia Scalia wyciągnął następujący wniosek: „Stwierdzenie, że niedyskryminacyjne ograniczenie zasady swobodnej praktyki religijnej jest dozwolone lub nawet pożądane nie oznacza, że jest ono konstytucyjnie wymagane, i że okoliczności stanowiące podstawę ograniczenia mogą być dostrzegane przez sądy. Można uczciwie rzec, że formułowanie takich okoliczności w procesie politycznym zadziała na niekorzyść praktyk religijnych, które nie są powszechnie wykonywane; lecz

16 Kodeks Missisipi, § 11-62-17(3).

17 Tamże, § 11-61-1(2). 
nieuniknioną konsekwencją rządu demokratycznego jest akceptacja systemu, w którym wolność sumienia jednostki jest ważniejsza od praw innych jednostek lub w którym sędziowie ważą społeczne znaczenie wszystkich praw w zderzeniu z kluczową rolą wolności religijnej"18.

Z tej właśnie przyczyny w przepisach MRFRA wyraźnie przewidziano, że celem ustawy jest przywrócenie poprzez akt ustawodawczy przesłanki sformułowanej w orzeczeniach Sherbert v. Verner z 1963 r. oraz Wisconsin v. Yoder z 1972 r. ${ }^{19}$ Te precedensy implikowały bowiem obowiązek władz publicznych do wykazania się ,,przemożnym interesem” na etapie uchwalania praw, które mogłyby zakłócać swobodę wykonywania praktyk religijnych. Jak przyjęto, „tylko najcięższe nadużycia, zagrażające najważniejszym interesom mogą stanowić podstawę dopuszczalnych ograniczeń" 20 .

Tak zatem - zgodnie z przepisami MRFRA - władza stanowa nie może ograniczać swobody praktyk religijnych, nawet jeśli zasięg oddziaływania danego środka ma charakter powszechny, chyba że przemawia za tym „przemożny interes”21, a przyjęte rozwiązania są najmniej restrykcyjne ${ }^{22}$. Podkreślenia również wymaga, że ustawa weszła w życie z mocą wsteczną, znajdując zastosowanie także do okresu przed $2014 \mathrm{r}^{23}$

18 Employment Division, Department of Human Resources of Oregon v. Smith, 494 U.S. 872, https://supreme.justia.com/cases/federal/us/494/872/ [dostęp: 30.07.2020]: But to say that a nondiscriminatory religious practice exemption is permitted, or even that it is desirable, is not to say that it is constitutionally required, and that the appropriate occasions for its creation can be discerned by the courts. It may fairly be said that leaving accommodation to the political process will place at a relative disadvantage those religious practices that are not widely engaged in; but that unavoidable consequence of democratic government must be preferred to a system in which each conscience is a law unto itself or in which judges weigh the social importance of all laws against the centrality of all religious beliefs. Por. Frankowski, Goldman, Łętowska 1998, 134-135. Zob. też Biłgorajski 2012, 100.

19406 U.S. 205 (1972).

20 Sherbert v. Verner, 374 U.S. 398 (1963), https://supreme.justia.com/cases/federal/ us/374/398/ [dostęp: 30.07.2020] oraz Thomas v. Collins [323 U.S. 516 (1945], https://supreme.justia.com/cases/federal/us/323/516/ [dostęp: 30.07.2020]: Only the gravest abuses, endangering paramount interests, give occasion for permissible limitations.

21 Szerzej: Prostak 2014, 91.

22 Kodeks Missisipi, § 11-61-1(5).

23 Tamże, § 11-61-7. 
W drugim $\mathrm{z}$ analizowanych aktów prawnych (HB 1523) expressis verbis wskazano, które przekonania religijne i moralne ${ }^{24}$ mają podlegać ochronie prawnej. Uwzględniono przekonanie, że małżeństwo jest związkiem mężczyzny i kobiety, że relacje seksualne są zarezerwowane tylko dla takiego małżeństwa oraz że pojęcia mężczyzny i kobiety dotyczą niezmiennej płci osób fizycznych determinowanej warunkami anatomicznymi i genetycznymi w czasie narodzin ${ }^{25}$.

Należy wyjaśnić, iż zakreślony w tenże sposób zakres ochrony nie sięga głębiej aniżeli Free Exercise Clause z Pierwszej Poprawki do federalnej Konstytucji. W dalszych przepisach omawianej ustawy (HB 1523) wymienia się zachowania, które są inspirowane i determinowane tymi przekonaniami.

Zważywszy na orzeczenie w sprawie Obergefell v. Hodges trzeba zauważyć, że wskazany wyżej cel ustawy określanej jako HB 1523 może powodować istotne wątpliwości konstytucyjno-prawne. Dlatego też zawarto w niej generalną klauzulę interpretacyjną. Z jednej strony zastrzeżono, że ochrona przewidziana $\mathrm{w}$ tym akcie normatywnym jest zgodna $\mathrm{z}$ porządkiem konstytucyjnym, z drugiej natomiast ograniczono zakres potencjalnych zarzutów o dyskryminację środowiska LGBT poprzez odwołanie do zasady najszerszej i maksymalnej ochrony wolności religijnej w granicach konstytucji federalnej i stanowej. Ponadto w przypadku kolizji z aktami prawa stanowionego, aktami administracyjnymi i orzeczeniami sądowymi, pierwszeństwo przyznano omawianej ustawie ${ }^{26}$.

W zamkniętym katalogu ujęto w omawianej ustawie (HB 1523) działania uznane za dyskryminacyjne wobec osób, których przekonania religijne lub moralne zgodne są z tradycyjnym postrzeganiem małżeństwa. Zaliczono do nich zmiany w przepisach podatkowych polegające na nałożeniu podatku, kary majątkowej, ograniczeniu lub wyłączeniu zwolnienia podatkowego, odmowę obniżenia podatku w związku z udzieleniem darowizny, uniemożliwienie lub wykluczenie z możliwości zawarcia umowy

24 W tym miejscu warto wskazać bardzo ciekawą publikację dotyczącą prawodawstwa Missisipi i omawianej ustawy w kontekście problematyki postrzegania się przez obie strony konfliktu jako ofiar dyskryminacji. Odnoszące się do tego rozważania, sformułowane z odniesieniem do listów wystosowanych przez Kościoły episkopalny, katolicki, metodystów i baptystów, opublikował jako tezy w dysertacji magisterskiej Bridenbaker 2018.

25 Kodeks Missisipi, § 11-62-3.

26 Tamże, § 11-62-15. 
publicznoprawnej lub udziału w stanowym programie pomocowym, jak też wprowadzenie niekorzystnej zmiany w treści takiej umowy, nakładanie kar finansowych, uniemożliwienie uzyskania certyfikatu, pozwolenia, dyplomu czy też innego dokumentu potwierdzającego kwalifikacje danej osoby, a ponadto odmowę zatrudnienia lub awansu, wymuszenie rezygnacji, zwolnienie, ukaranie oraz dokonanie niekorzystnej zmiany w umowie o pracę ${ }^{27}$.

Odrębnie uregulowano kwestię funkcjonowania organizacji religijnych i podejmowania przez nie decyzji warunkowanych potrzebą ochrony małżeństwa jako związku mężczyzny i kobiety. Tak zatem władze stanowe nie mogą dyskryminować organizacji religijnych ze względu na ich działania lub brak działań dotyczących zawarcia małżeństwa, wykonania lub odmowy wykonania usługi związanej z ceremonią zawarcia, uznania lub uczczenia związku małżeńskiego, podejmowania decyzji personalnych, w tym o zatrudnianiu, zwalnianiu, karaniu pracowników, których zachowanie lub przekonania religijne są sprzeczne z przekonaniami głoszonymi przez daną organizację, jak również podejmowania decyzji o sprzedaży budynków, najmie, zasadach pobytu lub zamieszkania przez osoby o określonych przekonaniach moralnych lub religijnych wskazanych w wyżej omówionym wyliczeniu ustawowym ${ }^{28}$.

Co więcej, chronione omawianą ustawą przekonania dotyczące małżeństwa i płci oraz wynikające $\mathrm{z}$ nich zachowania nie tylko mogą być uwzględniane przez organizacje religijne w procesie adopcji dzieci lub umieszczania ich $\mathrm{w}$ rodzinach zastępczych ${ }^{29}$, ale ponadto osoby, które adoptują dzieci lub tworzą rodziny zastępcze, nie mogą być dyskryminowane przez władze stanowe za to, że wychowują te dzieci zgodnie z tradycyjnymi przekonaniami oraz że wpajają takie poglądy dzieciom pozostającym pod ich opieką ${ }^{30}$.

Jest rzeczą oczywistą, że walka światopoglądowa nie przełoży się wprost na regulacje prawne ingerujące w przekonania religijne rodzin biologicznych. Jednakże sytuacja dzieci adoptowanych lub wychowywanych

27 Tamże, § 11-62-7.

28 Tamże, § 11-62-5(1)(a)(b)(c).

29 Tamże, § 11-62-5(2).

30 Tamże, § 11-62-5(3). 
w rodzinach zastępczych może - w zależności od interpretacji zasady separacji kościoła od państwa - nie być już tak jednoznaczna. Doskonale ilustruje to właśnie ustawa określana jako HB 1523, która zakazuje dyskryminacji organizacji religijnych wspierających adopcję dzieci, jeśli organizacje te są przeciwne małżeństwom jednopłciowym.

Wydaje się, że w opinii publicznej najwięcej kontrowersji budzą kwestie związane z odmową wykonania obowiązku przez urzędnika lub pracownika albo wykonania usługi przez osobę prowadzącą działalność gospodarczą z uwagi na przekonania religijne. W pierwszej kolejności omawiana ustawa odnosi się do tzw. klauzuli sumienia i w sposób wyraźny rozciąga ochronę na osoby, które w ramach wykonywanego zawodu odmawiają uczestnictwa w procedurach medycznych zmierzających do zmiany płci oraz prowadzenia usług psychologicznych, doradztwa lub usługach wykonywanych w klinikach medycznych, jeśli sprzeciwiałoby się to tradycyjnemu postrzeganiu małżeństwa i płci. Wyraźnie zastrzeżono przy tym, że odmowa wykonania świadczenia medycznego nie może dotyczyć przyjęcia pacjenta, uznania ważności upoważnienia do podejmowania decyzji w sprawie zdrowia czy też udzielenia pomocy medycznej w nagłych przypadkach $^{31}$.

W dalszej kolejności analizowany akt normatywny (HB 1523) reguluje problematykę odmowy wykonania usługi przez przedsiębiorcę ze względu na przekonania religijne lub moralne. Warto dodać, że w Polsce z uwagi na brak możliwości zawarcia związku małżeńskiego przez pary jednopłciowe, aktualnie nie budzi zainteresowania społeczeństwa kwestia odmowy wykonania usługi czy dostarczenia towaru w związku z ceremonią zawarcia takiego małżeństwa. W USA natomiast, wskutek legalizacji tychże małżeństw, pojawiały się zarzuty o dyskryminację osób homoseksualnych przez usługodawców, którzy sprzeciwiali się małżeństwom jednopłciowym. W rezultacie, w omawianej ustawie wyraźnie się stanowi, że osoby prowadzące określoną działalność gospodarczą mogą odmówić wykonania usługi lub sprzedaży towaru, jeśli towary lub usługi nabywane są w związku z zawarciem lub uznaniem małżeństwa pary jednopłciowej ${ }^{32}$. Dotyczy to fotografii, zaproszeń, rejestracji kamerą, planowania ślubów,

31 Tamże, § 11-62-5(4).

32 Zob. też: Chain 2016, 277-296. 
muzyki, ogłoszeń, dekoracji florystycznych, szycia ubrań, pieczenia tortu, wynajęcia sali, samochodu, biżuterii i innych podobnych, związanych ze ślubem, usług i towarów ${ }^{33}$.

W ustawie o ochronie wolności sumienia przed dyskryminacją ze strony władzy wprowadzono także zakaz dyskryminowania przez władze stanowe osób, które w prowadzonej przez siebie działalności gospodarczej ustalą wymagania dotyczące płci wobec swoich pracowników lub uczniów w kwestii korzystania z łazienek, stref spa, pryszniców, przebieralni, szatni oraz innych pomieszczeń, które muszą gwarantować poszanowanie intymności ${ }^{34}$.

Warto wspomnieć, że w odniesieniu do sektora prywatnego obowiązywanie zasady wolności religijnej nie rozwiewa wszystkich wątpliwości konstytucyjno-prawnych związanych z odmową wykonania usługi ze względu na przekonania religijne i nie usuwa całkowicie implikowanego ową odmową potencjalnego ryzyka zarzutu o dyskryminację. Jeszcze bardziej skomplikowany będzie układ wchodzących w grę praw i wolności w przypadku niezrealizowania określonego obowiązku przez osoby zatrudnione w sektorze publicznym, a to ze względu na zasadę rozdziału kościoła i państwa. Należy mieć przy tym na uwadze, że na gruncie amerykańskim zasada separacji może być różnie interpretowana w zależności od rozwiązań prawnych wprowadzanych w systemach stanowych. Jeśli rozwiązania te będą odpowiadać poglądom społecznie liberalnym, będzie to naturalnie wzbudzać sprzeciw środowisk konserwatywnych domagających się nie tylko poszanowania ich przekonań religijnych lub moralnych, ale i realizacji ochrony wolności słowa. Są to swego rodzaju dynamiczne fenomeny warunkowane sporem światopoglądowym i przewagą uzyskiwaną w danym czasie przez konkretną opcję, politycznie zdolną do zmiany prawa. Co więcej, nie sposób też uznać - przez pryzmat zasady rozdziału kościoła od państwa - za analogiczne odmowę wykonania usługi w sektorze prywatnym oraz odmowę wykonania obowiązku w administracji publicznej. W sytuacji bowiem osób, które są zatrudnione w instytucjach publicznych, najistotniejsze pozostaje pytanie, czy w ogóle mogą one dochodzić prawa do odmowy wykonania obowiązku służbowego, uzasadnia-

33 Kodeks Missisipi, § 11-62-5(5).

34 Tamże, § 11-62-5(6). 
jąc to przekonaniami religijnymi kwestionującymi dopuszczone prawnie stosunki społeczne.

Szczególnej analizy wymagają zatem te przepisy ustawy określanej jako HB 1523, które rozszerzyły jej krąg podmiotowy o osoby zatrudnione w administracji stanowej, gdyż wprowadzają one możliwość powołania się na klauzulę sumienia przez urzędników, których przekonania religijne i moralne sprzeciwiają się uznaniu małżeństw jednopłciowych. Rozważania te należy zacząć od uwagi, iż ogólna przesłanka wymaga, by zachowanie urzędnika było prawnie dozwolone. Samo to sformułowanie implikuje poważne wątpliwości o konstytucyjnym charakterze, zwłaszcza w kontekście federalnej supremacy clause i roli orzecznictwa federalnego Sądu Najwyższego, w tym przede wszystkim orzeczenia Obergefell v. Hodges. Zgodnie z omawianą ustawą urzędnik stanowy może korzystać z wolności słowa lub angażować się w agitację, wyrażając tym samym swoje przekonania religijne, nie tylko poza miejscem pracy i bez związku z wykonywaniem czynności służbowych, ale również w miejscu pracy, o ile takie działania ze względu na ich czas, miejsce, sposób i częstość mogą być podejmowane także przez osoby innego wyznania, mające odmienne poglądy polityczne lub moralne. Co do zasady urzędnik nie może odmówić wykonania czynności służbowej. Nie dotyczy to jednak sytuacji, w których zawierany jest związek między osobami tej samej płci. W tym bowiem przypadku ustawa reguluje, iż wszyscy urzędnicy, którzy w imieniu stanu wydają pozwolenia na zawarcie małżeństwa ${ }^{35}$, jak również, przed którymi zawierane są związki małżeńskie, mogą odmówić wykonania czynności urzędowych, gdy sprawa dotyczy zawarcia małżeństwa nieheteronormatywnego. Na etapie rozpatrywania wniosku o wydanie pozwolenia na zawarcie takiego małżeństwa urzędnik, którego przekonania religijne lub moralne nie pozwalają na jego uznanie, zobowiązany jest do złożenia oświadczenia o odmowie wpisu do rejestru aktów stanu cywilnego (State Registrar of Vital Records), jak również do dołożenia należytej staranności i podjęcia kroków, by dokonanie czynności urzędowej nie zostało uniemożliwione lub opóźnione. Gdy zaś czynność dotyczy już samego zawarcia małżeństwa, urzędnik jest zobligowany do złożenia oświadczenia o odmowie w Urzę-

35 W amerykańskich stanach do dziś jest to akt administracji publicznej, bez którego dokonania nie można wstąpić w związek małżeński. 
dzie ds. Administracji Sądowej (Administrative Office of Courts) i to ten urząd jest odpowiedzialny za zapewnienie, że czynności administracyjne zostaną dokonane bez żadnej zwłoki ${ }^{36}$.

W aspekcie skutków powyższego rozwiązania należy wyjaśnić, iż analizowana ustawa nie jawi się jako lex imperfecta. Zawiera bowiem przepisy wyposażające osoby fizyczne i prawne, których dobro zostało naruszone poprzez dyskryminację ze względów religijnych, w realny instrument przeciwdziałania. Podmiot, którego prawo do wolności religijnej zostało naruszone przez władzę stanową, może domagać się odszkodowania za szkody majątkowe i niemajątkowe, a także zwrotu kosztów ustanowienia pełnomocnika. Zgodnie z przepisami ustawy żądanie odszkodowania jest zasadne, jeśli poszkodowany uzyskał najpierw sądowy nakaz zaniechania (injunctive relief) dyskryminacji i dopiero ten nakaz został naruszony. Podstawowym zatem instrumentem prawnym jest wystąpienie do sądu o wydanie nakazu zaniechania ${ }^{37}$, przy czym nie stosuje się tu zasady wyczerpania środków administracyjnych ${ }^{38}$. Termin do wszczęcia procedury na mocy ustawy upływa dwa lata po tym, jak poszkodowany dowiedział się lub mógł się dowiedzieć o dokonaniu aktu dyskryminacji ${ }^{39}$. Jednocześnie, mimo szeroko w ustawie określonego katalogu działań, które mają dyskryminujący charakter, prawo Missisipi ogranicza możliwość pozywania stanu (zgodnie z Poprawką XI do Konstytucji federalnej) i dopuszcza odpowiedzialność prawną władzy publicznej tylko w odniesieniu do naruszeń prawa popełnionych $\mathrm{w}$ trakcie lub $\mathrm{w}$ związku $\mathrm{z}$ czynnościami służbowymi ${ }^{40}$. W konsekwencji, w odniesieniu do czynności administracyjnych dotyczących zawarcia małżeństwa, w praktyce stosowania prawa dochodzi do sytuacji, w których z jednej strony urzędnik, którego przekonania religijne podlegają ochronie prawnej odmawia wykonania czynności urzędowej, a z drugiej petent domaga się poszanowania zasady równości wobec prawa i ochrony przed dyskryminacją ze względu na orientację seksualną. Analizowane przepisy pozwalają urzędnikowi na odmowę wyko-

\footnotetext{
36 Kodeks Missisipi, § 11-62-5(8).

37 Tamże, § 11-62-11.

38 Tamże, § 11-62-9(2).

39 Tamże, § 11-62-13.

40 Tamże, § 11-46-5.
} 
nania czynności, pod warunkiem jednak, że nie zakłóci to funkcjonowania systemu administracji. Niemniej, jeśli urzędnik - mimo braku przeszkód prawnych - nie zgodzi się na wydanie pozwolenia, uzasadniając to swoimi przekonaniami religijnymi i wskutek tego pozwolenie nie zostanie wydane lub jego wydanie się opóźni, będzie mógł zostać pociągnięty do odpowiedzialności prawnej. W przypadku zaś gdy małżeństwo ma zostać zawarte, taki urzędnik odpowiedzialności ponosić nie będzie, ponieważ to nie na nim spoczywa obowiązek zapewnienia terminowego działania administracji, tylko na Urzędzie ds. Administracji Sądowej. Uzasadniona wydaje się zatem konkluzja, że konserwatywny ustawodawca w swoim sprzeciwie wobec małżeństw homoseksualnych rozszerzył wobec urzędników stanowych ochronę przed możliwością pociągnięcia do osobistej odpowiedzialności, jeśli odmawiają oni wykonania czynności administracyjnej.

\section{SPRZECIW WOBEC PRZEPISÓW O OCHRONIE WOLNOŚCI SUMIENIA PRZED DYSKRYMINACJĄ ZE STRONY WŁADZY}

Przewidywany na 1 lipca 2016 r. termin wejścia w życie ustawy określanej jako HB 1523 został przesunięty z powodu wydania przez federalny Sąd Okręgowy dla Okręgu Południowego Missisipi zakazu sądowego (preliminary injunction) w trybie badania przez władzę sądowniczą zgodności ustaw z Konstytucją federalną (judicial review). Otóż w dniu 30 czerwca 2016 r. sędzia Carlton Reeves po raz kolejny poparł roszczenia prawne środowiska LGBT i w związku ze sprawą Barber v. Bryant orzekł, że ustawa ta sprzeciwia się tradycyjnemu rozumieniu wolności religijnej oraz godzi w zasady równości wszystkich mieszkańców stanu poprzez narażenie środowiska LGBT na arbitralne decyzje dotyczące wykonania czynności lub usługi przez urzędników publicznych i sektor prywatny ${ }^{41}$. Gubernator Missisipi (oraz inni przedstawiciele władz stanowych) złożyli zapowiedź apelacji i wniosek o wstrzymanie wyko-

41 Barber v. Bryant, 193 F. Supp. 3d 677 (S.D. Miss. 2016), postanowienie Sądu Okręgowego dla Południowego Okręgu w Missisipi z dnia 30 czerwca 2016 r., https://docplayer. net/19595986-Case-3-16-cv-00417-cwr-lra-document-39-filed-06-30-16-page-1-of-60. html [dostęp: 30.07.2020]. 
nania zakazu. Taki wniosek - zgodnie z prawem federalnym - rozpoznawany jest przez sędziego wydającego zaskarżone orzeczenie. W postanowieniu z dnia 1 sierpnia 2016 r. sędzia Reeves tenże wniosek oddalił. Co ciekawe, w uzasadnieniu podniósł, że nawet jeśli skarżący powołują się na to, iż w związku z zawieszeniem wejścia w życie przedmiotowej ustawy (HB 1523) zostali oni nieodwracalnie pokrzywdzeni (irreparably injured), to „mieszkaniec Missisipi [...] mający przekonania wymienione w $\S 2$ ustawy, którym nadano specjalną ochronę, może odwoływać się do istniejących gwarancji wolności religijnej, wliczając w to Konstytucję Missisipi, ustawę o przywróceniu wolności religijnej oraz Pierwszą Poprawkę do Konstytucji Stanów Zjednoczonych. Brak obowiązywania ustawy HB 1523 nie narusza wolności wykonywania praktyk religijnych"42.

W ocenie sądu wnioskodawcy nie przedstawili żadnych argumentów na potwierdzenie, że brak obowiązywania tej ustawy spowoduje nieodwracalne szkody, a ponadto nie została spełniona również inna przesłanka wstrzymania wykonalności zakazu. Uwzględnienie wniosku nie służyłoby mianowicie interesowi publicznemu, bowiem wejście w życie ustawy mogłoby pociągnąć za sobą między innymi negatywne konsekwencje ekonomiczne ${ }^{43}$. Sędzia Reeves wyraźnie stwierdził, iż interes publiczny najlepiej zabezpieczy ,status quo - Missisipi bez HB 1523"44.

W dniu 22 czerwca 2017 r. federalny Sąd Apelacyjny dla Piątego Okręgu na skutek apelacji złożonej przez gubernatora od zakazu wydanego przez sędziego Reevesa w sprawie Barber v. Bryant oraz w sprawie Campaign for Southern Equality v. Bryant III orzekł o braku legitymacji procesowej (standing) powodów kwestionujących zgodność tejże ustawy z Konsty-

42 Barber v. Bryant, Cause No. 3:16-CV-417-CWR-LRA (S.D. Miss. Aug. 1, 2016), postanowienie Sądu Okręgowego dla Południowego Okręgu w Missisipi z dnia 1 sierpnia 2016 r., https:/casetext.com/case/barber-v-bryant-1 [dostęp: 30.07.2020]: A Mississippian $[\ldots]$ holding any of the beliefs set out for special protection in $\S 2$ may invoke existing protections for religious liberty, including Mississippi's Constitution, Mississippi's Religious Freedom Restoration Act, and the First Amendment to the United States Constitution. HB 1523's absence does not impair the free exercise of religion.

43 Po wejściu w życie ustawy wiele stanów i władz lokalnych wprowadziło ograniczenia w dofinansowaniu współpracy z podmiotami z Missisipi.

44 Barber v. Bryant, postanowienie Sądu Okręgowego dla Południowego Okręgu w Missisipi z dnia 1 sierpnia $2016 \mathrm{r}$. 
tucją federalną. W uzasadnieniu stwierdził, iż nie wykazano rzeczywistych szkód, które mogą powstać wskutek obowiązywania podważanego aktu prawnego ${ }^{45}$. Paradoksalnie, strona powodowa podniosła, że ustawa określana jako HB 1523 narusza prawa osób homoseksualnych w sposób analogiczny do przypadków, w których symbole religijne umieszczane w przestrzeni publicznej godzą w zasadę rozdziału kościoła od państwa. Sąd stwierdził, że w sporach z zakresu swobody wykonywania praktyk religijnych trzeba jednak wykazać konkretne, a nie abstrakcyjne naruszenie. Jednocześnie, ze względu na wspomniany wyżej brak legitymacji procesowej strony powodowej w postępowaniu o stwierdzenie niekonstytucyjności ustawy, sąd odwoławczy uchylił zakaz sądowy wydany przez sędziego Reevesa. Próby wzruszenia tego orzeczenia w drodze wniosku o ponowne rozpoznanie sprawy w pełnym składzie sądu apelacyjnego czy też wniosku o ponowne wysłuchanie okazały się bezskuteczne. W konsekwencji, ustawa o ochronie wolności sumienia przed dyskryminacją ze strony władzy (HB 1523) weszła w życie w dniu 10 października 2017 r.

Za kwintesencję poglądów, zgodnie z którymi omawiana ustawa zakłada dyskryminację osób homoseksualnych, można uznać opinię Amici Curiae, złożoną przez instytucje działające na rzecz środowiska LBGTQ w sprawie Barber v. Bryant do federalnego Sądu Najwyższego w trybie kasacyjnego odwołania się od wyroku sądu apelacyjnego. Odnoszące się do tego rozważania ograniczone zostaną do analizy tej części dokumentu, w której podejmowany jest temat przekonań religijnych środowisk konserwatywnych. W powyższej opinii przyjęto, że ,pytanie nie dotyczy tego, czy pomysłodawcy HB 1523 szczerze $^{46}$ wyznają określone przekonania religijne lub moralne, lecz czy te przekonania mogą usprawiedliwiać krzywdzące ustawodawstwo klasyfikujące, które szkodzi osobom LGBT"47.

45 W skrócie rzecz ujmując tzw. injury-in-fact stanowi jedną z przesłanek stwierdzenia niekonstytucyjności ustawy.

46 Tłumaczenie to najlepiej oddaje sens obowiązującej w prawie USA klauzuli sincerely held religious beliefs.

47 Opinia Amici Curiae złożona na rzecz LGBT przez Legal Advocates \& Defenders (GLAD) and National Center for Lesbian Rights, https://www.glad.org/cases/barber-v-bryant/ [dostęp: 30.07.2020]: The question is not whether HB 1523 proponents have sincerely held religious beliefs and moral convictions, but whether these beliefs can justify invidious class legislation that causes LGBT person harm. 
Udzielając na to pytanie odpowiedzi negatywnej, autorzy opinii powołują się na liczne już wówczas orzeczenia uznające takie rozwiązania za naruszenie Czternastej Poprawki. Argumentują, iż celem i skutkiem krytykowanej przez nich ustawy jest szeroko rozpowszechniona dyskryminacja i pokrzywdzenie osób LGBT poprzez uprzywilejowanie określonych poglądów religijnych. Za niewystarczające w świetle zmian legislacyjnych uznają oni argumenty strony przeciwnej, a mianowicie, że orzeczenie Obergefell v. Hodges sprzeczne jest z wizją małżeństwa zawartą w Biblii. W tym sensie ustawa skutkująca dodatkową ochroną przekonań religijnych jest niekonstytucyjna, gdyż dopuszcza dyskryminację ze względu na orientację seksualną lub tożsamość seksualną.

Federalny Sąd Najwyższy w dniu 8 stycznia 2018 r., podobnie jak sąd apelacyjny, odmówił merytorycznego rozpoznania sprawy ze względu na brak legitymacji procesowej strony powodowej. Aktualnie zatem Missisipi pozostaje stanem, w którym ustawodawca nie wykreślił ani z Konstytucji, ani z Kodeksu prawa przepisów niezgodnych z orzeczeniem Obergefell v. Hodges ${ }^{48}$ i jednocześnie wprowadził nową ustawę, która chronić ma tradycyjną wizję małżeństwa poprzez odwołanie do wolności religijnej.

\section{KONKLUZJE}

Przykład konserwatywnego Missisipi potwierdza, że trudno jest jednoznacznie rozstrzygnąć problem przeciwstawnych wizji małżeństwa poprzez prawne uregulowanie stosunków społecznych w tejże materii. W konflikcie bowiem, który nie może zostać złagodzony w formie kompromisu, poszanowanie poglądu przeciwnego tożsame będzie z dyskryminacją poglądu wyznawanego. W praktyce okazuje się też, że wdrażanie form pośrednich pomiędzy tradycyjnym małżeństwem a małżeństwem homoseksualnym (jak np. związki partnerskie, które w założeniu miały być właśnie kompromisem dającym osobom homoseksualnym pewną ochronę,

48 Wyjaśnienia wymaga, że wskutek wydania przez federalny Sąd Najwyższy orzeczenia w sprawie Obergefell v. Hodges, konstytucyjna definicja małżeństwa nie ma mocy obowiązującej. 
przy jednoczesnym utrzymaniu rozumienia małżeństwa jako związku kobiety i mężczyzny), nie zapewnia rozwiązań trwałych.

Uznanie przez federalny Sąd Najwyższy, że odmawianie przyznania osobom homoseksualnym możliwości zawierania małżeństw stanowi dyskryminację ze względu na zasadę równości, skutkowało podjęciem przez część stanów kroków legislacyjnych w celu - jak to ujmowano - przywrócenia wolności religijnej. Oczywiście, można dyskutować, czy celem tej legislacji była rzeczywiście ochrona określonych poglądów religijnych czy też chęć obejścia orzeczenia Obergefell v. Hodges. Nie zmienia to jednak faktu, że jeśli prawo dopuszcza małżeństwa osób tej samej płci czy też inne rozwiązania, które stoją w sprzeczności z określonymi przekonaniami religijnymi, wyznawcom takich przekonań nie można odmawiać prawa do ich artykułowania i podejmowania decyzji dotyczących ich życia osobistego i zawodowego w sposób zgodny z wiarą. Zagwarantowanie tego prawa teoretycznie można byłoby nazwać swego rodzaju kompromisem. W rzeczywistości jednak okazuje się, że taki kompromis nie stanowi skutecznego antidotum na konflikt, gdyż niemożliwe jest zrównoważenie zasad równości i wolności religijnej rozumianych zgodnie z koncepcjami przyjmowanymi przez przeciwne strony sporu.

Przykład Missisipi może z jednej strony skłaniać do konstatacji, że uznanie w porządku prawnym danego państwa małżeństw jednopłciowych powinno skutkować także konkretnym działaniem legislacyjnym w zakresie sprzeciwu sumienia i gwarancji swobody praktykowania religii, co umożliwiłoby osobom fizycznym i prawnym - których religia lub światopogląd sprzeciwiają się takim małżeństwom - obronę przed zarzutami o dyskryminację. Regulacje takie muszą być jednak w najwyższym stopniu wyważone i nie mogą stanowić podstawy do działań faktycznie dyskryminacyjnych, dokonywanych jedynie pod pozorem korzystania z wolności religijnej. Z drugiej strony wszak, obserwacja ewolucji zmian w prawie Missisipi ukazuje, iż wprowadzane rozwiązania dające ochronę jednej ze stron sporu ze względu na potrzebę zapewnienia zasady egalitaryzmu wywołują dążenia do dalszego ,poprawiania prawa” i zamiast zmniejszać poszerzają merytoryczny zasięg konfliktu.

Niewątpliwie należy spodziewać się także podejmowania przez środowiska sprzeciwiające się opisanemu wyżej ustawodawstwu Missisipi dalszych prób orzeczenia jego niekonstytucyjności, zwłaszcza że kwestia 
ta - jak dotąd - nie została rozstrzygnięta merytorycznie. Biorąc zaś pod uwagę aktualny skład Sądu Najwyższego USA oraz podnoszone przez środowiska konserwatywne zarzuty ograniczenia wolności słowa w zakresie definiowania małżeństwa zgodnie z tradycyjnym jego rozumieniem, nie można wykluczyć rozszerzenia $\mathrm{w}$ drodze judicial review dotychczasowego znaczenia wolności religijnej wynikającego z Pierwszej Poprawki do federalnej Konstytucji.

\section{BIBLIOGRAFIA}

Bridenbaker, Jonathan Eugene. 2018. Distance and Sympathy in Public Argumentation on HB 1523: Four Pastoral Letters Creating Value Frameworks. Honors Theses, 584. https://aquila.usm.edu/honors_theses/584.

Biłgorajski, Artur. 2012. „Wolność słowa vs. wolność religijna. Wybrane zagadnienia”. Studia Politologiczne 23: 95-120.

Chain, Raygan Pierce. 2016. „The prize of citizenship? How a cake baker and wedding photographer paid the price". Southern Law Journal 26: 277-296.

Frankowski, Stanisław, Roger Goldman, Ewa Łętowska. 1998. Sąd Najwyższy USA. Prawa i wolności obywatelskie. Warszawa: OSCE.

Hodge Jr., James G. 2015. ,Respecting religious freedoms and protecting the public's health". Law and The Public's Health 130: 546-549.

Kazyak, Emily, Kelsey Burke, Mathew Stange. 2018. „Logics of Freedom: Debating Religious Freedom Laws and Gay and Lesbian Rights". Socius: Sociological Research for a Dynamic World 4: 1-18.

Linton, Paul Benjamin. 2013. „Religious Freedom Claims and Defenses under State Constitutions". University of St. Thomas Journal of Law and Public Policy 2: 103-191.

Longchamps de Bérier, Franciszek. 2016. „Sądowa instytucjonalizacja małżeństwa osób tej samej płci w Stanach Zjednoczonych". Forum Prawnicze 6: 3-15.

Łącki, Paweł. 2016. „Konstytucja a małżeństwo. Prawa podstawowe i demokracja”. Przeglad Sejmowy 1: 169-183.

Machaj, Łukasz. 2019. „Między sankcjonowaniem kryminalizacji aktów homoseksualnych a konstytucjonalizacją małżeństw osób tej samej płci - przyczynek do rozważań o roli Sądu Najwyższego w Stanach Zjednoczonych". Studenckie Prace Prawnicze, Administratywistyczne i Ekonomiczne 28: 377-396.

Prostak, Rafał. 2014. „Małżeństwa jednopłciowe i interes publiczny w orzecznictwie amerykańskiej judykatywy”. Przeglad Sejmowy 2: 89-106. 
Wróbel, Agata Jagna. 2016. „Małżeństwo osób tej samej płci - Obergefell v. Hodges i inni”. W: Identyfikacja granic wolności i praw jednostki. Prawnoporównawcza analiza tożsamego przypadku pod katem praktyki stosowania prawa amerykańskiego i polskiego, red. Mariusz Jabłoński, 125-141. Wrocław: E-Wydawnictwo. Prawnicza i Ekonomiczna Biblioteka Cyfrowa. Wydział Prawa, Administracji i Ekonomii Uniwersytetu Wrocławskiego, http:// www.bibliotekacyfrowa.pl/dlibra/publication/79781.

FREEDOM OF RELIGION AS AN INSTRUMENT OF LEGAL PROTECTION FOR OPPONENTS OF SAME-SEX MARRIAGES.

THE CHANGES IN MISSISSIPPI LAW

AFTER THE OBERGEFELL $V$. HODGES CASE

Abstract

The article considers the legislative changes which have been recently implemented in Mississippi, initiated by the advocates of traditional marriages in response to the legalization of same-sex marriages. Special attention is paid to the Mississippi Religious Freedom Restoration Act and the Protecting Freedom of Conscience from Government Discrimination Act. In relation to the abovementioned acts and the Obergefell $v$. Hodges case, this article provides both a description of the actions that have been taken by the conservative parts of Mississippi's society and counteractions by the LGBT movement and its supporters. The analysis shows the tension between equality and religious freedom due to the different ways in which they are interpreted by the antagonistic groups. This leads to the conclusion that this conflict may not be efficiently resolved through a legal compromise. However, as is hypothesized in the article, religious freedom may become an important legal instrument for protecting opponents of same-sex marriages from discrimination claims when their religion does not allow them to recognize such marriages.

Key words: freedom of religion; equal protection clause; same-sex marriages; Mississippi HB 1523 